\title{
Theorising Nigerian Crime Problems
}

\author{
DOI http://dx.doi.org/10.4314/mlr.v10i1.7
}

\section{Abstract}

O. Aigbovo* and Osose Eidenoje**

This comment presents an overview of criminological theories of crime and examines some contemporary crime problems in Nigeria against the backdrop of relevant theories. It also analyses society's response to each crime problem in the form of government policies and legislation. The paper argues that an appreciable understanding of the different crime theories is fundamental for an effective response to contemporary crime problems and that the response so far has not been reflective of such understanding. It is therefore recommended that criminal policy makers in the legislative, executive and judicial arms of government in Nigeria should be knowledgeable about crime theories so that they can fashion well informed policies, legislative and judicial responses to Nigerian crime problems. Lastly it is recommended that Nigeria should adopt best practices from other jurisdictions in combating its crime problems since its attempts so far have not succeeded.

Key terms: Nigeria, Crime, Theories, Corruption, Best Practices.

\section{Introduction}

A theory refers to a formal set of ideas which is intended to explain why something happens or exists. ${ }^{1}$ It is any system of ideas arranged in rational order that produces general principles based on facts which increase our understanding and explanations ${ }^{2}$. Explanations are important because they help

\footnotetext{
* Dr Aigbovo is an Associate Professor in the Department of Public Law, University of Benin, Benin City, Nigeria. Email: osaretin.aigbovo@uniben.edu

** Mr Eidenoje is a Barrister and Solicitor of the Supreme Court of Nigeria and LL.M candidate in the Faculty of Law, University of Benin, Benin City, Nigeria. Email: eidenojeosose@gmail.com

The authors are grateful to the editor who reviewed the earlier draft of this paper for his helpful observations which have helped in enriching the paper.

${ }^{1}$ Oxford Advanced Learner's Dictionary, Special Price Edition, S. Wehmeier (ed) (Oxford: OUP, 2001) p.1241 s.v. "theory."

${ }^{2}$ A. Kaplan, The Conduct of Social Inquiry (San Francisco: UCP, 1964), cited in T. O’Connor, "Crime Theories in the Field of Criminology," p.1, available at: <http://www.drtomoconnor.com/1010/1010lect02.html>. Accessed May 27, 2015.
} 
us figure out why things are the way they are and suggest ways to effect desired changes. $^{3}$ There are many theories for the explanation of crime. However no single theory or definition can be exhaustive on the issue of crime. ${ }^{4}$ A major objective of criminological research is to provide theoretical explanations for crime, with a view to finding ways of curtailing crime in society. ${ }^{5}$ Crime is generally defined in terms of some form of deviance or behaviour which departs from the prevalent societal norms. From the legal perspective, crime has been defined as "an act capable of being followed by criminal proceedings". 6 Section 2 of the Criminal Code Act, Chapter C38, Laws of the Federation of Nigeria, 2004 (Criminal Code ), uses the term “offence”, which it defines as "an act or omission which renders the person doing the act or making the omission liable to punishment". ${ }^{7}$ Crime problems ${ }^{8}$ are widespread incidences of particular crimes at different times which pose difficulty to the society.

This paper gives an overview of contemporary crime theories. It then analyses notable crime problems in Nigeria and the response of the political authority to each of the crime problems. For our purpose, the phrase 'political authority' refers to the formulators of criminal policy in the executive, legislative and judicial arms of government. Theoretical explanation of each crime problem is made, with the aim of suggesting effective ways of responding to same. The crime problems discussed are corruption, armed robbery, advance fee fraud, kidnapping and terrorism. These crimes are the prevalent crime problems in Nigeria. Some relevant solutions are preferred on how the political authority will benefit from an understanding of crime theories.

\footnotetext{
${ }^{3}$ H.D. Barlow, Criminal Justice in America (New Jersey: Prentice, 2000), p.86.

${ }^{4}$ L. Atsegbua, "The Nature, Definition and Function of the Criminal Law," Nigerian Bar Journal, 7, No. 1 (2011): p.238.

${ }^{5}$ Criminology has been defined as the study of crime as a social phenomenon. It includes within its scope the process of making laws, of breaking laws, and of reacting towards the breaking of laws. The objective of criminology is the development of a body of general and verified principles and of other types of knowledge regarding this process of law, crime and treatment or prevention. See E.H. Sutherland, Principles of Criminology, $2^{\text {nd }}$ Edition (Philadelphia: Lippincott, 1934), p.6.

${ }^{6}$ G. Williams, “The Definition of Crime,” CLP, 8 (1955): p.107.

${ }^{7}$ See also s.28 of the Penal Code, Chapter P3 Laws of the Federation of Nigeria, 2004. While the Criminal Code applies to areas in the former Southern Nigeria, the Penal Code applies to areas in the former Northern Nigeria.

8 A problem is a thing that is difficult to deal with or understand. Oxford Advanced Learner's Dictionary, s.v. "problem”.
} 


\section{Crime Theories}

Most policies which are directed towards tackling particular crime problems fail due to ignorance, misapplication or misinterpretation of criminological theories. ${ }^{9}$ Crime control and prevention would be more effective if policy makers and operators of the criminal justice system understand and apply the relevant theories on the causes of crime. This is because having a fair understanding of a problem facilitates proffering of appropriate solutions for dealing with it. Crime theories are criminological assumptions which are held by different scholars about the causes of crime and are aimed towards an explanation for criminal behaviour.

Classical criminology sought to explain crime based on free will, and the pleasure and pain principle. Offenders were thought to engage in crime after weighing the level of satisfaction derivable, set off against the punishment attached if apprehended. Cesare Beccaria posited that crime was as a result of an expression of the free will of offenders i.e. offenders rationalised whether or not to engage in crime. ${ }^{10}$ Classical postulations were philosophical explanations of crime, without taking cognizance of the influence of external factors. Classical criminology helped to shift attention from earlier notions that criminality was caused by evil spirits and it focused attention on the nature of legislation and adjudication.

However, Darwin's theory of evolution afforded opportunity to challenge classical theory. ${ }^{11}$ Scientific approach was introduced into criminological inquiry, giving rise to positivist criminology. Positivist criminology bases theoretical explanations on observed facts and perceives crime as resulting from the influence of external factors on the offender. This is also known as the deterministic approach to crime. It has helped in shifting the focus from the nature of legislation and adjudication to the offender peculiarity. About 13 criminological theories have been identified, ${ }^{12}$ with 3 being considered as mainstream, into which others can be conveniently subsumed. Mainstream theories are biological, psychological and sociological explanations of crime.

${ }^{9}$ O’Connor, “Crime Theories in the Field of Criminology,” supra, note 2.

${ }^{10}$ F. Adler, G.O.W. Mueller and W.S. Laufer, Criminology and the Criminal Justice System, $6^{\text {th }}$ Edition (Boston: McGraw Hill, 2007), p.63.

${ }^{11}$ Charles Darwin published his Origin of Species in 1859, in which he claimed that God did not create the various species of animals, but that each had evolved through a process of adaptation. In 1871, he published the theory on the Evolution of Man in The Descent of Man and Selection in Relation to Sex, which posited that man evolved from the anthropoid ape. See Adler et al, infra note 13, p. 67.

${ }^{12}$ O’Connor, “Crime Theories in the Field of Criminology,” supra, note. 2 


\subsection{Biological theories}

These trace crime to the genetic, morphological and anthropological make up of offenders, who are thereby considered inferior to non-offenders. Cesare Lombroso postulated his theory of the 'born criminal', which assumes that offenders are defective in anthropological constitution e.g. by possessing atavistic stigmata such as unusual eye pigment, long arms and linking eyebrows etc, which makes them prone to crime. ${ }^{13}$ Scholars like Ernest Hooton, Ernst Ketschner and Richard Dugdale traced criminality to particular body types and hereditary traits transferrable from parents to children. ${ }^{14}$ Biological theories generally recommend policies which are directed towards the isolation and treatment of offenders as a way of checking crime in society. ${ }^{15}$ This includes preventive measures like the provision of improved living standards and placement in special homes where offenders are made to be accustomed into suppressing display of potential criminal characteristics.

\subsection{Psychological theories}

These theories explain crime as manifestation of the imbalanced psyche of offenders. Rafaele Garofalo, ${ }^{16}$ in the earliest of psychological explanations of crime, traced criminal behaviour to moral anomalies. Sigmund Freud founded psychoanalysis, which propounds that offenders have a weak superego, thereby lacking restraint against the urge for momentary gratification. ${ }^{17}$ According to this theory, the human psyche is broken into the id, ego and superego. The ego constantly seeks to achieve a balance between urges and drives for gratification i.e. id and honed personal moral codes i.e. the superego. The superego is dependent on personal judgement about moral questions as an inter-play between the mental state of the individual, vis-à-vis the level of psychological development or mental health. If there is no balance in a person`s psyche, then he is prone to committing crime. The moral development theory sees offenders as those with defective moral development or suffering from psychiatric challenges. ${ }^{18}$ Offenders are predicted to be reacting to stress, suffering from low intelligence quotient or a psychopathic state of mind. This theory generally

${ }^{13}$ Adler, Freda, Mueller, Gerhard O.W. and Laufer, William S. (2007), Criminology. $6^{\text {th }}$ Ed. McGraw Hill, p.68.

${ }^{14}$ Ibid, p.72.

${ }^{15}$ However, scholars like Enrico Ferri recommend capital punishment in appropriate cases for offenders who are found to be incorrigible. See Adler et al, Criminology, p.70.

${ }^{16}$ Adler et al, supra note 13, p.68.

${ }^{17}$ Ibid, p.85.

${ }^{18}$ The major proponent of this theory is Lawrence Kohlberg, who formulated the theory of moral development. According to this theory, offenders reason at a pre-conventional level, more like adult-children. 
recommends therapeutic treatment and counselling for offenders in a bid to reintegrate them into society and curb crime.

\subsection{Sociological theories}

Sociological theories of crime explain crime as a product of the social conditions of an individual. The works of Adolphe Quetelet ${ }^{19}$ and others which demonstrated that crime statistics vary in relation to factors like poverty, age, sex, race, neighbourhood etc, laid the foundation for several postulations and sub-theories, which may be conveniently grouped as sociological. These include the following theories:

a) Ecological theory: ${ }^{20}$ This theory traces criminality to the nature of the immediate environment of offenders and blames crime on the disorganisation of neighbourhoods, rather than the kinds of people living there. ${ }^{21}$ Scholars like Gabriel Tarde found that majority of offenders began as street urchins in overcrowded, unplanned and disorderly ghettos. In the din of disorganisation, a survival of the fittest atmosphere inheres, temptation to indulge in crime is intensified and those at the bottom of the food chain imitate those at the top. Postulations of this theory recommend proper town planning, resettlement schemes and practical community empowerment as a way of discouraging criminality in society.

b) Strain theory: This perceives crime as resulting from efforts by offenders to circumvent blockages to the actualisation of economic goals. Foundational to this is the anomie theory propounded by Emile Durkheim, which states that crime is as a result of breakdown of social order due to loss of values. Expanding on this, Robert Merton $^{22}$ traced crime to a lack of integration between what urban culture demands of individuals and what the existing social structure permits. Everyone is expected to attain the same level of success per time e.g. live in a comfortable home, get married and give support to dependants, yet the means of achieving these things or getting to the top is not evenly distributed among all social classes. The result is a disjuncture of social order as persons who belong to the lower classes, often with less opportunities, try to make it to the top at all cost. The individual resorts to all manner of means, including indulging in crime, in order to actualise his or her economic goal. This theory recommends increased opportunities for all across the social classes. $^{23}$

\footnotetext{
${ }^{19}$ Adler et al, supra note 13, p.75.

${ }^{20}$ O’Connor, “Crime Theories”, supra, note 2.

${ }^{21}$ Ibid, p.2.

${ }^{22}$ Adler et al, supra note 13, p.117.

${ }^{23}$ O’Connor, “Crime Theories”, supra, note.2.
} 
c) Learning theory: This postulates that crime is as a result of rearing or enculturation. The influence of peer groups, childhood heroes and role models comes to mind. Edwin Sutherland's differential association theory postulates that imitation of behaviour is relative and dependent on factors like intimacy, frequency, intensity and priority of relationship between learner and his role model. ${ }^{24}$ Repetition of delinquency is subject to the reward system in place and learned criminal behaviour tends to be repeated, fine-tuned and intensified or reinforced when they are rewarded positively. Therefore, hooliganism is learned when offenders have the protection of law enforcement and politicians. This theory recommends more effective negative reinforcement and use of positive reinforcement as a way of checking crime e.g. revamping the reward system in society in such a way as to discourage delinquency and encourage citizens to be law-abiding.

d) Control theory: This perceives crime as resulting from ineffective bonding between offenders and agents of socialisation/authority figures such as parents, teachers, law enforcement agents, religious, cultural and political leaders etc. Expanding on this theory, E.A. Ross postulated that the belief systems rather than specific laws guide what people do and generally serve to control behaviour. Individuals take to crime when such belief systems which ought to make them conform to societal laws are weak or absent. This results in reverse-socialisation and low self-control or outright failure of containment among e.g. street gangs, children from broken homes, failure in educational system or corrupted political and socio-cultural structure. ${ }^{25}$ Proponents of this theory recommend proper child-rearing, reintegration and conscious restoration of social bonds through rehabilitation therapy as a way of curtailing criminality.

e) Labelling theory: This theory holds that criminality results from role-play by offenders of society's script. According to Howard S. Becker, moral entrepreneurs, who are people whose high social position empowers them to make and enforce social rules by which members of society live by, often label certain persons as deviants or potential offenders e.g. the general belief that persons from humble backgrounds may be tempted to steal, or that ghetto dwellers are miscreants. ${ }^{26}$ The labelling process develops through shunning of first offenders and general condemnation instead of seeking ways to sincerely reintegrate such persons. The individual experiences a sort of social excommunication from society, integrates into a class of criminals and is immersed into the identity of an offender. This theory discourages profiling of

\footnotetext{
${ }^{24}$ Adler et al, supra note 13, p.135.

${ }^{25}$ See Id., p.168.

${ }^{26}$ H.S. Becker, Outsiders: Studies in the Sociology of Deviance (New York: Macmillan, 1963), pp.9-20.
} 
members of some social classes and races due to previous crimes committed by them or their counterparts. Proponents recommend non-intervention by moral entrepreneurs in incidences of deviance and reintegration of offenders as solutions to crime problems.

f) Conflict theory: It perceives crime as resulting from the struggle for domination by members of competing interest groups in society ${ }^{27}$ e.g. the imaginary cold war between the rich and the poor, adults and children, the ruling class and the ruled etc. George Vold and other scholars propounded that laws are made by members of the ruling class in such a way as to benefit them and suppress the lower classes. ${ }^{28}$ The result is that most conducts of members of the lower classes often run counter to the law. This theory recommends the promotion of equality in society as a way of reducing the conflict and the incidence of crime. Giving equal opportunity to all segments of society to make inputs into laws and policies tends to give individuals a better sense of belonging and encourage persons to be law-abiding.

g) Radical theory: This is based on the economic theories of Karl Marx, which states that aspects of social life and laws are determined by capitalists or economically advantaged individuals in society to the disadvantage of others. Based on that reasoning, Bonger postulates that capitalism encourages criminal behaviour by creating an atmosphere that is inconvenient for social responsibility. Thus, crime is designed to favour capitalists in so far as offenders may be used as a source of cheap labour while undergoing punishment, like imprisonment coupled with hard labour. ${ }^{29}$ Class struggle and capitalism is therefore blamed for crime as members of the proletariat or labour strive to succeed against the dictates of the few capitalists in whom economic power is concentrated. As a way of preventing and controlling crime, this theory recommends resort to praxis in equitable economic structure or socialism which ensures that major means of production are not concentrated in a few.

h) Left Realism theory: This perceives crime as resulting from predatory relationships among members of the different working classes. It recommends effective policies as a solution to crime problems.

i) Peacemaking theory: This perceives crime as resulting from inner suffering and turmoil of offenders. Crime fighting only deteriorates the situation

\footnotetext{
${ }^{27}$ It has been argued that deviance is not a quality of the act the person commits, but rather a consequence of the application by others of rules and sanctions to an offender. The deviant is one to whom that label has successfully been applied; deviant behaviour is behaviour that people so label. See Becker, Outsiders, p.9.

${ }^{28}$ O’Connor, “Crime Theories”, supra, note 2.

29 See A.W. Bonger, Criminality and Economic Conditions, Trans, H.P. Hooton (Boston: Little, Brown, 1916), p.669.
} 
as offenders are manifesting their frustration. This theory recommends spiritual rejuvenation and the creation of more caring, mutually dependent communities as a way of providing inner peace to offenders and curbing crime. ${ }^{30}$

j) Feminist theory: This perceives certain types of crime as resulting from the patriarchal nature of society and gender inequality which creates pressures on the male figure to be able to attain certain standards of living, marry and provide for the household. Concept of male domination is blamed for various crimes in society. It recommends ending sex discrimination as a solution to crime problems. ${ }^{31}$

k) Post modernism theory: The theory traces criminality to a disconnection between offenders and societal conceptualisation. Crime is seen as developing from feelings of dehumanisation due to estrangement of the individual by stereotypes, general thinking and conception, thereby limiting the individual's understanding. Crime becomes a reaction against such dehumanisation and overemphasis on scientific rationality to the pursuit of knowledge. This appears to justify the existence of extremism among those who feel that society has grown worse due to modernisation. This theory recommends the promotion of more informal social controls as a replacement to current legal system e.g. the use of group and neighbourhood tribunals. ${ }^{32}$

l) Culture conflict theory: The theory perceives crime as resulting from conflict due to the different cultural backgrounds of persons in society. ${ }^{33}$ Different groups, religious, tribal, cults etc, have different norms and which tend to conflict with the norms of the dominant group in society; the norms of dominant groups often translate into and are upheld by society in the form of laws and policies. For example, some tribal groups practice wife stealing in which case, desirable damsels are abducted for the purpose of marriage. In an urban setting, such practice may incur criminal sanction. This theory recommends correctional education and non-intervention as a solution to crime problems.

\footnotetext{
${ }^{30}$ O’Connor, “Crime Theories”, supra, note 2.

31 Ibid.

${ }^{32}$ Ibid.

${ }^{33}$ Ibid.
} 


\section{Nigerian Crime Problems: Overview of Selected Offences}

\subsection{Corruption}

Corruption is synonymous with dishonesty or illegal behaviour, especially of people in authority. It is the act or effect of making somebody change from moral to immoral standard of behaviour. ${ }^{34}$ Under section 2 of the Corrupt Practices and Other Related Offences Commission Act, 2000, (Chapter C31, Laws of the Federation of Nigeria, 2004) (ICPC Act hereinafter), corruption is defined as including "bribery, fraud and other related offences". Historically, the origin of corruption in Nigeria predates the colonial era. ${ }^{35}$ A Colonial Government Report in 1947 noted that “Africa's background and outlook on public morality is very different from that of the present day Briton. The African in the public service seeks to further his own financial interest". ${ }^{36}$ However, corruption seems to have been alien to traditional systems in Africa. The report thus seems to have made reference to practices by office holders in the course of the transition to modern tiers of authority.

The political history of Nigeria suggests that corruption became significantly visible during the $1^{\text {st }}$ Republic around $1963 .{ }^{37}$ The colonial government had just relinquished power to the locals, most of who had lived simple lifestyles as nationalists and were mostly from the middle social classes. They were naturally overwhelmed by the cheap victory or the fact that Nigeria's independence was won on a platter of gold. They found themselves in control of the booming resources of the new nation, a task many were untrained for or less exposed to. This was unlike the pre-independence and pre-republican days when a majority of the nationalists strived to pursue the cause of the people.

Another factor was pressure from the better exposed key players of the business sector, most of whom had lobbied contracts from the colonialists. Automatically, they turned to the nationalists' leaders. Nationalists became beneficiaries of most of the local businessmen and women, patronising them during the post independence era in gratification of their earlier support and

\footnotetext{
${ }^{34}$ Shuaibu Kassim Abubakar, “Anti-Corruption Crusader in Nigeria: Can the Self-acclaimed Giant of Africa be Salvaged? (1)," Edoworld available at <http://www.edoworld.net> accessed on October 25, 2014.

35 Michael .M. Ogbeide, "Political Leadership and Corruption in Nigeria since 1960: A Socio-economic Analysis”, Journal of Nigeria Studies, 1, No. 2 (2012): p.1.

${ }^{36}$ Ibid. This is not to say that corruption in the criminal context is a part of the African culture. Corruption everywhere is a vice, only that some cultural practices and norms tend to fall under corruption as known in the modern day e.g. giving gifts to people in authority in appreciation for a kind gesture may amount to "gratification", which is prohibited under s.2 of the ICPC Act.

${ }^{37}$ Abubakar, “Anti-Corruption Crusader in Nigeria”, supra note 34.
} 
sponsorship of nationalist movements-cum-political parties. The result was the invention of a new form of corruption termed 'official corruption'. Most business moguls became political godfathers of the nationalists. Contracts were overpriced in return for kickbacks to government officials. ${ }^{38}$

Widespread official corruption was one of the excuses used by those behind the military coup d'état of January 15, 1966, in toppling the government of the $1^{\text {st }}$ Republic, ${ }^{39}$ as a reaction to the crime of official corruption in Nigeria. There were subsequent coups which thrived on the same issue. Thus, when the democratic government of President Shehu Shagari was toppled by the military junta led by General Mohammadu Buhari, many Nigerians took to the streets in jubilation on the assumption that the reign of corruption had ended. ${ }^{40}$ They made heroes of the military government, when it subsequently sacked and prosecuted many public officers. Many fled overseas in search of asylum e.g. Umaru Dikko, a former Transport Minister whom the military claimed was in possession of huge amounts of embezzled funds. ${ }^{41}$

But the psyche of the people, especially the lower classes had been affected. The chequered political terrain affected the social norms in line with the anomie theory of Emile Durkheim, due to a succession of breakdown of social order as a result of loss of standards and values, as the country moved from colonial rule to democratic self-governance, military interventions, civil war, military rule and back to democratic rule. Values became difficult to sustain. During the civil war, there were alleged sharp practices by businesspersons who were contracted to make supplies to the forces at the war zones. Most of them corrupted the military commanders to short-change the government by making under-supplies and supplying inferior qualities.

Another malpractice was the invention of 'ghost' soldiers; salaries of dead soldiers were still being paid by some syndicates of finance officers to themselves. The result is that members of the military who were themselves inexperienced in administration became exposed to corruption. In the long run, some military leaders ended up looting Nigeria's treasuries. Since the return of democratic rule to Nigeria in 1999, official corruption has taken a new dimension. Some of those in government or who occupy key positions in the

${ }^{38}$ Many Nigerian writers have satirised the transition of erstwhile pauper nationalists-cumpoliticians into millionaires during the transition. See generally e.g. Chinua Achebe's book A Man of the People and "The Voters" in Girls at War and Other Stories (London: Heinemann, 2002), p.11.

39 Abubakar, supra note 34.

${ }^{40}$ Ibid. See also Smurfy, "Umaru Dikko: The failed Abduction,” July 3, 2014, Nairaland, available at <http://www.nairaland.com>. Accessed on October 7, 2014.

${ }^{41}$ Ibid. 
private sector were involved as demonstrated in FRN v. DSP Alamieseigha ${ }^{42}$ and FRN v. Cecilia Ibru. ${ }^{43}$

The Criminal Code and Penal Code prohibit corruption. Moreover, the ICPC Act, the Economic and Financial Crimes Commission Act 2000 (EFCC Act), the Money Laundering Act 2011 (as amended) ${ }^{44}$ and several other statutes were enacted in response to the new wave of official corruption and white collar crimes after the return of democracy in 1999. A major challenge has been the attitude of prosecutors and the seeming inability of the justice system to secure convictions. For example in the above cases, the EFCC had to enter into plea bargain in contrast with the case of accused persons of lesser social classes. Another issue is the rather ridiculous fines meted out by the courts e.g. in FRN v. Yusuf, ${ }^{45}$ the accused pensions board member stood trial for the theft of over $\$ 40$ billion but was fined $\$ 750,000$. This sparked up public outcry as many condemned the attitude of the judiciary, which tended to be directed in favour of members of the upper classes. This case appears to be a dramatisation of the conflict theory which assumes that laws are made by members of the upper classes who try to ensure that such laws are in their favour, creating continuous conflict between the social classes in a struggle for supremacy.

The Nigerian government adopted a legalistic approach to the problem of corruption by enacting different statutes and establishing special agencies like the EFCC and ICPC. However, corruption still lingers. An understanding of the theoretical basis of corruption in Nigeria would have led to the adoption of more effective measures aimed towards curbing crime. Gift, is for example, is cultural in Nigeria, and the cultural conception of gift becomes a bribe when the recipient holds authority to make decisions which positively or negatively

${ }^{42}$ (2006) 16 NWLR (Part 1004) 1.

${ }^{43}$ Cited in I. Akeregha et al, `The Ruling Class has Corrupted the Judiciary-Femi Falana` 32 (17) The Source Magazine, available at <http://www.thesourceng.com>. Accessed on 15 October 2014. See also Akingbola v FRN (2012) 9 NWLR (Part 1306) 475, where the appellant was charged with the theft of over N47 billion belonging to the defunct Intercontinental Bank Nigeria Plc.

${ }^{44}$ Other anti-corruption mechanisms include the Central Bank of Nigeria Regulation or BVD-biodata captured and to have a unique number to which all bank accounts which requires everyone to have his opened by him can be traced. This aims towards curbing the incidence of fictitious bank accounts in order to avoid money laundering and related offences. The Public Procurement Act is also aimed at curbing overprizing and nontransparent award of government contracts. The Freedom of Information Act also serves as a check as under that Act any interested members of the public may enquire about any information from any authority.

${ }^{45}$ Cited in I. Akeregha et al, "The Ruling Class has Corrupted the Judiciary: Femi Falana SAN” February 11, 2013, 32 (17) The Source Magazine available at <http://www.thesourceng.com>. Accessed on October 14, 2014. 
affects the gift provider. What the law, at present, regards as gratification from bribe, was from a cultural perspective perceived as a show of appreciation.

Nigeria is made up of over 300 tribal groups with different cultures. Virtually all of them recognise the giving of gifts as a sign of appreciation in return for or in anticipation of favours. From the perspective of culture conflict theory, when citizens bring this culture into dealings with public officials, it turns out to be the crime of corruption. Therefore, Nigeria`s anti-corruption provisions criminalising official gratification introduced from the time of the colonial administration to the present day are impositions of a foreign norm alien to the ordinary Nigerian coming from a cultural background which sees the giving and taking of gratification, whether official or not, as an acceptable norm.

These anti-corruption statutes are perceived as huddles intended to hinder the lower classes from acquiring easy wealth and crossing over into the ruling classes. This reflects the conflict theory. Corruption in Nigeria also lends credence to the learning theory as persons who previously lived honest lives soon learn, based on social, political and economic interactions that virtually all those who have succeeded are or were involved in corruption, one way or the other; from the departmental director who bribed his way into office, to a political office holder who used forged credentials, bribed voters and electoral officers or otherwise rigged his way into office, to the successful entrepreneur or politically exposed person who wins his contracts based on gratification of government officers or abuse of power. As a matter of fact, the innocent often finds that the more he shuns corruption, the more opposition he meets along the upward ladder. Corruption then has an appearance of conduct which is better rewarded than honesty. This increases the rate of imitation among members of the public, and validates Sutherland`s differential association theory of learning crime. It is therefore not surprising that attempting to tackle the crime problem of corruption through legal means alone has failed.

Corruption could be tackled through education directed towards correcting wrong cultural values. There should also be political education, provision of equal opportunity and easy access to desirable things of life to reduce the strain on individuals in striving to attain societal goals. There should be an overhaul of Nigeria's reward system by positive reinforcement and effective negative reinforcement. This requires rewarding honesty and ensuring the certainty and celerity of punishment of corruption as postulated by scholars like Beccaria, who argued that certainty and celerity of punishment is strong deterrent to the commission of crime. 


\subsection{Armed robbery}

The Criminal Code and the Robbery and Firearms Act (Chapter R11, Laws of the Federation of Nigeria, 2004), criminalised robbery. ${ }^{46}$ The offence becomes armed robbery when the robbery involves the use of an 'offensive weapon' or any firearm. Under section 11 of the Robbery and Firearms Act, offensive weapon includes "any article (apart from a firearm) made or adapted for use for causing injury." Firearms include any gun, explosive, ammunition whether whole or detached. Armed robbery has been classified into the following: ${ }^{47}$

a) Contract Robbery: This involves the recruitment of robbers for the sole purpose of executing a robbery operation based on agreed fees or share between the informant or procurer and the robbers e.g. this usually manifests in form of attacks on bullion vans, leaking of information about the presence or movement of money or other valuables. There is usually high rate of causalities as the robbers operate like assassins; ready to succeed at any cost.

b) Pre-planned Robbery: This involves the conscious study of routine security lapses of the target within a given period by an insider or spy e.g. robbing a bank or museum.

c) Opportunity Robbery: This takes place when occasion presents itself e.g. robbers or potential robbers roaming the streets may run into a target. There is high probability of apprehension as the robbers may run out of firepower or may be overwhelmed by other circumstances outside their control.

d) Snap Robbery: This is at a local level and small-scale e.g. persons with access to firearms may decide to utilise them for immediate satisfaction of a particular need when broke or as a past time e.g. cultists who have just been initiated and are asked to prove their guts, rogue law enforcement agents, hunters, herdsmen or political thugs.

e) Revenge Robbery: This happens in retaliation for perceived wrong e.g. retrenched staff, swindled business partners etc. It could get bloody as the robbers may become assassins while in action.

The categories highlighted above indicate types of robberies. Ajayi groups robbers into ${ }^{48}$ the following:

a) Psychotic Robbers: These posses the do-or-die, kill or be killed attitude. They are hardened criminals; jail birds mostly. They are usually merciless and may be fugitives from law enforcement agents. They could be described as professional robbers, with a sense of mission; as if they have a limited

\footnotetext{
${ }^{46}$ See s.401 of Criminal Code and s.2 (1) of Robbery and Firearms Act.

47 Gabriel A. Ajayi (2011), "Crime and Security: The Menace of Armed Robberries in Nigeria.” Available at: <http://nigeriaworld.com/articles/2011/oct/241.html>

${ }^{48}$ Ibid.
} 
period of time within which to operate. They are often on a robbery spree in the company of gang members.

b) Normal Robbers: These operate with the aim of enjoying their loot. They live normal lives and may even have known means of livelihood. They hold their lives as dear. They are rarely armed, easily caught and could be described as amateur robbers.

In Nigeria, armed robbery became a significant phenomenon shortly after the civil war (1967-1970). ${ }^{49}$ The immediate causes are not farfetched. Both separatist forces and some members of Nigeria`s Armed Forces, especially volunteers and those who were conscripted, had just been disbanded and much of the arms used in prosecuting the war had not been effectively mopped up. There were several clusters of abandoned arms and combat gear which soon found their way into wrong hands. ${ }^{50}$ The temptation to go into armed robbery increased due to the economic setback and austerity which followed the end of the war as many people lost their means of livelihood and properties to the war. A remote cause was the influence of soldiers mixing with civilians during the war; many wives abandoned their husbands for soldier-lovers and many soldiers turned looters, especially among the non-professional soldiers. ${ }^{51}$ This resulted in paradigm shift as the people soon realised the power of 'the man with the gun.'

Aside from the social effect, there was also the psychological effect. Some notorious armed robbers and their collaborators tended to be psychotically heartless with regard to the manner in which they carried out their robbery operations. One of such was Ishola Oyenusi a.k.a. 'doctor rob and kill', ${ }^{52}$ who

${ }^{49}$ A.G. Karibi-Whyte, Criminal Policy: Traditional and Modern Trends (Lagos: Nigerian Law Publications, 1988) cited in Merenin Otwin, "The Anini Saga: Armed Robbery and the Reproduction of Ideology in Nigeria,” Journal of Modern African Studies, Vol. 25 (2) undated: p.259.

${ }^{50}$ See generally Chinua Achebe’s “Civil Peace” in Girls at War and Other Short Stories. See also Cyprian Ekwensi's Survive the Peace. Sir Billy Ozimede of Ate Village, Agenebode Edo State, recounted in a personal interview on October 5, 2014, how he witnessed as a teenager during the days following the end of the civil war heaps of abandoned rifles in an open place near the barracks in his hometown and how many locals armed themselves at will.

${ }^{51}$ E.g. the Biafran Army contingent which besieged Benin City around August 9, 1967, in the preliminary days of the civil war allegedly looted the Central Bank and major businesses located in the business districts. N.A. Omoigui, "The Midwest Invasion of 1967: Lessons for Today’s Geopolitics”, October 3, 1998 (Keynote Address at the Nigeria Independence Day Celebration hosted by Nigerian Women Association in South Carolina, USA) available at <http://www.edo-nation.net/midwest.htm> accessed on October 2, 2014.

52 Olayinka Ogunshe, "Doctor Ishola Oyenusi: The Execution of Notorious Nigerian Armed Robbery,” December 4, 2013, Alabamau, available at 
smiled all the way to the execution stand. He terrorised Lagos by his ferocious operations, leaving a trail of death behind. Others like the notorious Lawrence Nomayagbon Anini ${ }^{53}$ directed their ferocity towards law enforcement agents in retaliation for perceived swindling by the police, which had allegedly led to the capture and execution of some members of his gang. ${ }^{54}$ Some armed robbers acted by 'direct learning'. Others displayed what has been described as 'moral insanity'. ${ }^{55}$ Most of them came from humble backgrounds and broken homes, with scarce home training e.g. Ishola Oyenusi had told journalists that he would not have gone into armed robbery if his parents had been financially capable enough to send him to school. ${ }^{56}$

In response to the wave of armed robbery after the civil war, the military government promulgated the Robbery and Firearms Decree (now Robbery and Firearms Act, CAP R11 Laws of the federation of Nigeria, 2004) which imposed death sentence by firing squad. People avoided travelling by night and banks started using armoured bullion vans to transport bulk cash. People started constructing high fences around their houses and fixing all sorts of anti-burglary protectors. In spite of the death penalty imposed, the menace of armed robbery did not abate; rather robbers became more brutal knowing that they would be executed if caught, an eventuality foreseen by Cesare Beccaria who argued in favour of proportionality of punishment. ${ }^{57}$

In the late 1990s, armed robbery became more sophisticated. This was due to improvement in technology, the proliferation of cults in higher institutions and

< http://www.alabamau2.blogspot.com>. Accessed on October 7, 2014. He was executed by firing squad on September 8, 1971. As at that date, about 70 robbers had been executed in Nigeria.

${ }^{53}$ P.E. Igbinovia, “Wound Ballistics, Reasonable Force and Anini’s Incapacitation,” Vol. 12, Issue 1, International Journal of Comparative and Applied Criminal Justice (1988): p.131. Anini`s gang terrorized Benin City and environs in the 1980s. He was rumoured to be a spirit, possessing potent charms that made him invincible to gunshot and could make him disappear.

${ }^{54}$ Merenin Otwin, “The Anini Saga”. There was the rumour that police collaborators blew his cover in spite of the kickbacks and bribes given to them. Interestingly, a superior police officer was indicted as a member of Anini's gang and was subsequently executed along with other gang members on March 29, 1987. Anini`s gang allegedly shot and killed at sight 9 policemen within a space of 3 months.

${ }^{55}$ Pinnel cited in Adler et al, Criminology. Many gangs are given to smoking and substance abuse, which keeps them high while in operation. Interestingly, Anini was said to have smoked a cigarette shortly before his execution.

${ }^{56}$ Igbinovia, "Wound Ballistics", supra, note 53.

${ }^{57}$ Beccaria was not in support of the death penalty, as he reasoned that imposing death penalty may cause criminals to become more deadly knowing that they would be executed if caught. 
political thuggery. ${ }^{58}$ While most post-civil war armed robbery gangs had top ranking law enforcement agents or influential military officers who acted as protectors and arms suppliers, their counterparts from the late 1990's to the present day have political godfathers who use them as political thugs, assassins or standby militias. There is also the existence of various armed ethnic militias. The government's response to armed robbery included legal approach like enactment of the Criminal Code and the Robbery and Fire Arms Act, and adoption of policies of law enforcement which provide the police with more arms, armoured vehicles and other gadgets aimed at crime fighting. The imposition of capital punishment for armed robbery has not effectively tackled it or prevented potential offenders from indulging in it.

However, it is posited that an understanding of crime theories would enable the political authority to fashion out more effective response to curb the crime of armed robbery. For example, the crime of armed robbery can be explained using the ecological, strain, learning, control, labelling, control and radical theories. From observation, armed robbery offenders are mostly young males under societal pressure or strain to achieve success by all means. ${ }^{59}$ Many offenders begin by involving in petty crimes like shoplifting and often get labelled in the process by family members, neighbours and other social observers. Later on in life, they find themselves acting in line with such lines as 'you will soon become a robber' with which they are tongue-lashed. Many offenders are from lowly backgrounds, broken homes and ghettos, which confirms the radical, ecological and control theories. Such offenders apparently indulge in robbery in an attempt to gather enough funds to transform themselves into successful people like capitalists. The fact that most of them come from disorganised neighbourhoods shows that their containment level against temptation to indulge in crime is either weak or absent. Most offenders have also taken to robbery due to interaction with successful robbers, in line with the learning theory.

As theorised, armed robbery would be effectively curbed by the reintegration of offenders, pursuing praxis socialism and ensuring that economic power is not concentrated in a few. Also, job and other opportunities for social and economic advancement should be made available to all regardless of social class. Our reward system should be revamped by rewarding hard work. Rather than emphasizing capital punishment as the principal means of deterrence, certainty of detection with the aid of modern forensic investigation methods and celerity of punishment should be introduced and institutionalised. Proper child-rearing

${ }^{58}$ Ajayi, “Crime and Security”. Bombs, grenades, bullet proof vehicles and small machine guns have been used by robbers, especially after the year 2000; most targets were banks and bureau the change.

${ }^{59}$ This tends to justify feminist theory as most robbers are males as if in show of their male dominance. 
and conscious restoration of social bonds through rehabilitation should be promoted. Male domination should also be deemphasized e.g. by cultural reorientation tending to reduce pressure on the male figure as the only one in the marriage relationship who must be able to marry and sufficiently provide for the wife and household. This would go a long way in reducing the pressure on males and, also, the general strain in society.

\subsection{Kidnapping}

Section 364 of the Criminal Code punishes kidnapping with 10 years jail term. However, various state anti-kidnapping laws prescribe capital punishment for the offence if death occurs in the process of kidnapping. ${ }^{60}$ Kidnapping may be categorised as follows:

(i) Kidnapping for extortion (ransom, to influence business decisions or to obtain commercial advantage);

(ii) Kidnapping between or within criminal groups (example, for debt recovery or to secure an advantage in a criminal market).

(iii) Kidnapping for sexual exploitation e.g. reported cases of kidnappers who raised children from their female victims.

(iv) Revenge kidnapping.

(v) Kidnapping for political or ideological purposes. ${ }^{61}$

Another pattern of classifying kidnapping is the typology identified by Pharaoh $^{62}$ who classifies it into (i) criminal kidnapping (involving hostage taking for ransom); (ii) political kidnapping (to settle political scores or further some political objectives), and (iii) pathological kidnapping (which involves parental kidnapping and kidnapping for sexual or slavery purposes). Yang ${ }^{63}$ adds a fourth typology which is culturally motivated kidnapping. This refers to kidnapping as practiced in some local communities e.g. bride capture, in which young women of marriageable age are kidnapped to be married by their captors, who may eventually return to pay the necessary bride price to the parents of their victims.

${ }^{60}$ E.g. Edo State Kidnapping (Prohibition) Law 2012 (as amended), ss.2 and 3, where no death occurs, it carries a maximum punishment of life jail term.

${ }^{61}$ United Nations Office of Drugs and Crime Document (UNODC-2003:7-8) available at $<$ http://www.unodc.org>. Accessed on October 2, 2014. See also M. Turner, "Kidnapping and Politics," Vol 26, International Journal of the Sociology of Law, (1998): p.145.

${ }^{62}$ Nseabasi S. Akpan, “Kidnapping in Nigeria's Niger-Delta: An Exploratory Study,” Vol. 24(1), Journal of Social Sciences, (2010): p.33.

${ }^{63}$ Ibid. 
Kidnapping became rampant in Nigeria during the agitations for resource control in the Niger Delta ${ }^{64}$ around the early 1990s until the amnesty days in 2008. The post 1990 agitators clamoured for a greater share from the crude oil drilled in the region. Other reasons included environmental degradation due to oil exploration and gas flaring, and exclusion from the management activities of oil companies. The agitations culminated in the execution of Ken Saro Wiwa and others by the military regime of late Gen. Sani Abacha in November 1995. ${ }^{65}$

After that period, most agitators took to arms, and several militant groups such as the dreaded Movement for the Emancipation of the Niger Delta (MEND) emerged. The agitators appeared to have borrowed a leaf from the late Isaac Adaka Boro, who declared independence for the Niger-Delta in February 23, 1966, but was later suppressed by the Nigerian government. The militants vandalised oil installations and kidnapped high profile individuals and foreign expatriates to drive home their demands e.g. to mount pressure on the federal government to release some of their arrested members. ${ }^{66}$ Their actions attracted international attention. In response, the government inaugurated a joint military task force comprising members of the armed forces. Many were charged with the offence of treason under the Criminal Code. ${ }^{67}$ It was not until amnesty was granted to the militants by the then government of late President Musa Yar'Adua that militancy-driven kidnapping abated.

However, commercial kidnapping for ransom by non-militants became rampant after the amnesty. Tzanelli ${ }^{68}$ describes the various dimensions of kidnapping in the Niger-Delta to include:

(i) Kidnapping as part of the general liberation struggle

(ii) Kidnapping for economic reasons-this is regulated by the laws of demand and supply, and is a type of social action that involves the calculation of the most efficient means to the desired end. This is justified by the strain subtheory of the sociological theory of crime. Many who had sought an easier

${ }^{64}$ Akpan, "Kidnapping in Nigeria’s Niger Delta”, 35. The Niger Delta includes the 6 states of the south-south of Nigeria, Akwa-Ibom, Bayelsa, Cross-Rivers, Delta, Edo and Rivers, and marginal Niger Delta states like Ondo, Imo and Abia.

65 Ibid.

${ }^{66}$ Id., at p.38. E.g. in May 2006, Militants kidnapped some foreigners in Port Harcourt following the refusal by Shell BP to pay $\$ 1.5$ billion compensation ordered by the court. Several $\$ 100$ Million were paid as ransom before expatriates regained their freedom in Akwa-Ibom, Warri and Port Harcourt. Other crimes introduced by the crime of kidnapping include illegal oil bunkering and arms dealing.

${ }^{67}$ Section 37.

${ }^{68}$ R. Tzanelli, "Capitalizing on Value: Towards a Sociological Understanding of Kidnapping,” Vol. 40, Sociological, (2006): p.929. 
way of achieving economic success had found a shortcut by resorting to kidnapping.

(iii) Kidnapping as a political tool

(iv) Kidnapping as a new crime; career kidnapping.

Many local businesspersons were made to pay ransoms before their release. Even judges and other public officers were not spared. In response, various antikidnapping laws were enacted, imposing death penalties. A majority of kidnapping charges are pending. A common feature is that most of the victims belong to the upper class, business moguls, political figures and relations of politically exposed persons or wealthy businessmen. These classes of persons usually mount pressure on the police, DSS and department of public prosecution to ensure that persons accused, mostly of the lower classes, are apprehended and prosecuted. However, this appears not to be the case when accused persons are from the upper classes. For example, in the case of Pius Ogbuawa v. FRN ${ }^{69}$, a notable business figure was charged with 20 others for the kidnapping of some expatriates, who were staff of a competitor company in Anambra State. The incident took place around March, 2007, but trial could hardly commence until around January, 2012. Critics have expressed displeasure over the delay which was apparently due to the influence of the accused persons. ${ }^{70}$

Insurgents in the northern part of Nigeria have also employed the tactics of kidnapping as a means of pressing home their demands. ${ }^{71}$ Government's response to kidnapping as part of the Niger-Delta militancy was in the form of amnesty, in return for public renunciation by offenders. However, post-amnesty kidnapping has received a legalistic approach by the enactment of various antikidnapping state laws and commissioning of more crime fighting equipment, and training for law enforcement agents. Yet, to nip the crime problem in the bud, an understanding of its theoretical basis is required.

From the perspective of the conflict and radical theories, kidnapping in Nigeria became a crime problem as a result of power struggles between the downtrodden members of oil producing communities and multinational oil

69 (2011) LPELR-CA/E/293C/2010.

${ }^{70}$ Emmanuel Obe, “Court Begins Trial in Anambra Kidnap Case”, January 28, 2012, Punch, available at <http://www.punchng.com>. Accessed on September 12, 2014. There were several preliminary applications made by the accused decided upon by the trial court and appealed to the Supreme Court. The substantive trial is ongoing as at the time of this research.

71 “Chibok Girls: Military Arrests Businessman for Alleged Involvement”, BusinessDay, July 1 2014, available at <www.businessdayonline.com> . Accessed on October 31, 2014. In mid-April 2014, 276 female students of the Federal Government Girls College, Chibok, Borno State were allegedly abducted by the insurgents. 219 of them have remained in captivity in spite of government`s negotiations. 
companies, between members of the lower classes and ruling class, the rich and the poor, between the commoners who feel neglected and the capitalists who have control of natural resources and oil wealth. From the perspective of post modernism theory, kidnapping resulted from disconnection in societal bondages and shared aspirations thereby resulting in the estrangement of individual offenders and limited individual perceptions in societal conceptualisation.

Commercial kidnappers perceive their venture as purely business, a means to an end-economic empowerment-whereas society sees it as a crime. Kidnapping is also explained by the strain theory, as offenders see it as a means of achieving quick economic success without going through the legally recognised route. Kidnapping can also be rationalised by the differential learning theory, as offenders are attracted by the economic improvements of role models who became successful through militancy in the Niger-Delta. The amnesty given to Niger-Delta militants served as negative reinforcement as many who had indulged in kidnapping of expatriates went scot-free with their ransom loot. In addition, they were paid large sums of money and university or vocational education under the amnesty programme. This encouraged post-amnesty kidnapping in Nigeria.

As a way of nipping kidnapping in the bud, equal opportunities should be given to members of the lower classes to aspire into positions in which they too could become resource-controllers. This includes, but not limited to, ensuring fair recruitment exercises, giving scholarships to indigent members of oil producing areas, providing portable water, roads and other critical infrastructure for the Niger-Delta and requiring and monitoring companies that operate in the region to adopt more community and environmentally friendly practices.

Praxis socialisation policies should be employed to ensure that wealth is not concentrated in the hands of a few, thereby increasing the temptation to indulge in kidnapping. More informal social controls should be promoted with the aim of closing the gap between offenders and society in terms of conceptualisation e.g. group tribunals should be constituted and resorted to rather than regular courts, in order to simplify complicated trial process. Executive prerogatives like amnesty should be resorted to only as last resort. Our reward system should be reoriented to discourage offenders. Offenders should be reintegrated via community based programmes.

\subsection{Terrorism}

Terrorism is a collection of illegal acts or threats which is calculated to instil fear and confusion in members of the public with the aim of compelling the government to agree to the demands of the perpetrators. It is a transnational 
crime $^{72}$ which is often associated with dissident groups and involves series of other offences like mass murders, suicide bombing, bombing of unguarded places, plane hijacking, kidnapping, cyber attacks, hostage taking etc. In Nigeria, acts of terrorism can be traced to the civil war in which Biafran forces hijacked Nigerian planes conveying dignitaries, making certain politically related demands. Several bombings of unguarded places and facilities within Nigerian territory were also recorded.

During the Niger-Delta agitations for resource control, acts of terrorism were employed by the militants to press home their demands; oil installations were bombed and expatriates kidnapped in protest of the detention of their comrades. More recently, the activities of religious extremists in northern Nigeria have taken the form of terrorism; suicide bombings, mass murders and kidnappings, ${ }^{73}$ guerrilla warfare attacks on unguarded civilians and armed forces etc. In the case of the Niger-Delta militants, a joint task force was constituted and deployed to fight the militants. When it appeared as if the problem could not be solved by the use of armed force, the amnesty programme was introduced in which militants who publicly renounced were enlisted into a reintegration and rehabilitation scheme.

The amnesty programme drastically reduced terrorism in the Niger-Delta, though some militant groups have refused to key into the amnesty programme. In the case of the Boko Haram terrorism in northern Nigeria the government made offer of amnesty, but it was refused. The government has therefore directed its efforts towards upgrading military hardware and training of the joint task force in its fight against religious extremists. At the same time, the Terrorism (Prevention) Act, 2011, was enacted which prohibits terrorism related acts as a felony and prescribed maximum capital punishment where death occurs. ${ }^{74}$ In spite of the foregoing, terrorism has lingered on in Nigeria. A better understanding of the theoretical basis of terrorism would aid in proffering solutions to nip it in the bud.

First, the practice of almajiri in northern Nigeria by which children who fall within the developmental stages of 5-14 are left to roam the streets without proper parental care under the excuse of religious training has a negative effect on the moral development of individuals. In line with psychological theory, this practice affects the psyche of individuals as they soon lack the appropriate moral code or super ego to be able to exercise containment or social bonds. They become virtually heartless and are potential recruits for religious extremists,

\footnotetext{
${ }^{72}$ See generally UN Convention Against Transnational Organised Crime, UN/Gen/ Ass/Res/55/25 of November 15, 2000.

${ }^{73}$ E.g, the Chibok Girls saga in 2014.

${ }^{74}$ See s.1 of the Terrorism (Prevention) Act 2011 (as amended).
} 
hence cases of suicide bombings and heinous attacks which have been recorded in northern Nigeria.

Terrorism in Nigeria can also be explained by ecological, conflict, radical, peacemaking, post modernism, control and culture conflict theories. Many supporters of religious extremists in the North are ghetto dwellers, street urchins and illiterate and unenlightened poor rural dwellers in remote and disorganised villages. The ecological setting renders them vulnerable to religious extremism. Similarly, many south-south militants are camp dwellers in inaccessible watersides, shanty towns, environmentally wrecked and disorderly alleys in the creeks of the Niger-Delta.

Terrorism in Nigeria also resulted from conflict between the rich and the poor, city dwellers and rural dwellers e.g. between Niger-Delta militants seeking resource control and oil companies and government, with control over oil wealth; conflict between uneducated indoctrinated northern rural/city slum dwellers who feel disconnected or that modernisation has disconnected them from mainstream society and that they have been dehumanised, oppressed or misled. Many religious extremists also appear to be manifesting their inner sufferings and turmoil as propounded by peacemaking theorists. Embittered by the fact that modernity has taken over the society, they go as far as indulging in suicide bombing and other acts in a bid to reverse the trend. The almajiri arrangement, under which children at critical developmental stages are left uncatered for by parents, weakens the containment of such individuals as explained by the control theory. Militants and religious extremists are indoctrinated into engaging in terrorism as a result of enculturation. Based on the culture conflict theory, terrorism is a display of the norms of the different cultures of offenders. Offenders are trained to see terrorism as the solution to their sufferings.

Ending terrorism from the theoretical perspective involves imbibing proper child-rearing and reintegration policies. ${ }^{75}$ Equal opportunities should also be given to all across segments of society to aspire into desirable positions, get good education and employment. Policies that ensure that wealth is not concentrated in a few should be vigorously pursued. Offenders found to be morally deficient or psychologically defective should be given therapeutic treatment. Spiritual rejuvenation, vis-à-vis religious reorientation, should be given to extremists. Correctional education and enlightenment should be given to offenders to reposition their reasoning aright.

\footnotetext{
${ }^{75}$ E.g. Lagos State extended maternity leave to 6 months for mothers and introduced 10 days for fathers.
} 


\subsection{Advance fee fraud}

The offence involves obtaining property or money by false pretence or false representation. It is prohibited under section 419 of the Criminal Code as a felony by 7 years jail term. Under section 1 of the Advance Fee Fraud and Other Related Offences Act, 2006, it is punishable with a minimum of 7 years jail term. The 2006 Act expands the scope of the offence to include fraud and money laundering via online or internet network in Nigeria or elsewhere. In addition to imprisonment, restitution is also to be made to victims. ${ }^{76}$ Advance fee fraud became popular in Nigeria during the mid 1980s when syndicates of money doublers swindled unsuspecting victims of fortunes, under guise of being in possession of money-making chemicals. It also took the form of ponzi schemes, notable among which was one by the name Plan Well. ${ }^{77}$

During the mid 1990s, online fraud otherwise called yahooism, which involved the use of scam mails, became rampant. Online fraud was usually designed along the infamous Spanish prisoner mail, promise of marriage, unsolicited joint venture proposals etc. Due to initial strained international relations with most western countries, the Nigerian government under the military did not take online scam seriously as most victims were based overseas, though legislative action was taken against advance fee fraud committed within the country. Many successful scammers, mostly youthful males, seemingly enjoyed the haven-like atmosphere. Several of them became multimillionaires overnight, flaunting their loot in form of expensive cars, hosting lavish parties and renting high class hotels for months on end. Most scammers and fraudsters are intelligent unemployed youths, university and secondary school graduates, and drop-outs from lowly backgrounds, and soon recruited more of their kind.

Scam syndicates were formed, with members hoping to hit it big. Even locally-based Nigerians became victims. This version of advance fee fraud was perceived as the easiest and quickest way to move from poverty to limelight. More youths were attracted into advance fee fraud because of the general strain in society and the reward for those who had been engaged in it. It resulted into

\footnotetext{
${ }^{76}$ Section 11 of Advance Fee Fraud and Other Related Offences Act, 2006.

${ }^{77}$ Eromosele Abiodun, `SEC, Ponzi Schemes and Investor`s Cry for Help`ThisDay Live 13 November 2013, available at <http://www.thisdaylive.com>. Accessed on 12 August 2014. It is named after Charles Ponzi, whose fraudulent investment company defrauded subscribers huge sums in the US in the 1900 `s, giving profits to contributors and dividends to subscribers without genuinely investing the company`s funds, until it leaked. In Nigeria, it is estimated that about 440 of such schemes have cost the public an estimated sum of \#106.9 billion, with over 560, 882 victims. Prominent among such schemes in Nigeria was Plan Well Limited which swindled many people around the late 80`s/early 90`s in Benin City and A2W Avenue to Wealth, Lagos, which was recently cracked down by Nigeria`s Aroma Oteh-led SEC in 2013.
} 
international scandal for Nigeria as most foreigners began to perceive anything Nigerian online as suspect. In response, the EFCC was given jurisdiction to clamp down on offenders, besides the police and other authorities. The Advance Fee Fraud and Other Related Offences Act and the Money Laundering Act were enacted, and amended to cover emerging versions of the offence.

Telecommunications operators were required to compulsorily keep details of their users, cybercafés were routinely inspected, courts required down payments of reasonable percentage of alleged moneys defrauded before granting bail, banks were required to keep special record of customers, track money transfers, report suspicious transfers to EFCC, NDLEA and other agencies, and international money transfer platforms required payees to have verifiable bank accounts into which their transfer can be made. Several prosecutions have been made and many advance fee fraud syndicates exposed, yet the offence has lingered. However, a better understanding of crime theories would have yielded better results.

Based on the strain theory, advance fee fraud, especially as it has to do with unemployed educated youths, came as a result of societal pressure on individuals to exhibit high level of success without minding how they do so. 419 and online fraud was resorted to as a means of attaining such success in order to get social approval from their peers, parents and the society. Advance fee fraud is also explained by the theory of differential association under the learning theory, as many offenders were attracted to the crime due to the apparent reward of successful fraudsters. The high esteem in which most successful fraudsters were held by all, including cultural and religious leaders, and the apparent protection they enjoyed due to the initial indifferent posture taken by law enforcement agents and the government, led to a general weakening of the belief systems of offenders in line with the control theory. Advance fee fraud can also be traced to the notion of male domination, as most offenders are males who are apparently attempting to prove their manhood by all means. It also has left realism and radical undertones, as offenders assume a predatory posture towards unsuspecting business individuals and advantaged personalities in a bid to have a fair share of the unevenly distributed wealth.

For the offence of advance fee fraud to be rooted out of society, there should be increased job opportunities based on a fair and transparent recruitment system which guarantees equality across the social classes. There should be proper child-rearing and conscious restoration of social bonds, vis-à-vis revamping of our value system. Our reward system should also be revisited, to ensure that honest labour is rewarded and admired rather than questionable illgotten wealth. There should also be effective policing by the adoption of proactive technological-based measures and male dominance should be deemphasized. 


\section{Best Practices in Some Jurisdictions}

As discussed above, most of the crime problems in Nigeria results from poor governance. In Nigeria, as in most African and developing countries, corruption is the key culprit of poor governance which has led to social disequilibrium. ${ }^{78}$ Corruption is therefore implicated as a major cause of crime. ${ }^{79}$ There is the need therefore to reduce the rate of corruption if the crime problems bedevilling the country are to be successfully tackled. However, although Nigeria has set up two anti-corruption agencies, corruption is still endemic in the country. What therefore are the best practices in the fight against corruption which have worked in some countries with backgrounds similar to that of Nigeria?

A link has been established between high public conscientiousness and compliance with the rule of law by governors in societies with active civic participation. ${ }^{80}$ There is more compliance in those societies, like the advanced democracies, where there is such active citizen participation. ${ }^{81}$ In this regard, lessons can be drawn from countries such as Kenya and Tanzania with regard to broad based efforts in the combat against corruption. Even more so, the schemes used and the achievements gained in corruption control in countries such as Hong Kong and Singapore are recommended for Nigeria and other countries which are under the grip of pervasive corruption. In Kenya, the National Tax Payers Association helps to sensitize citizens on how political office holders expend public funds. Their oversight has exposed some discrepancies through its periodic Citizens Report Card. ${ }^{82}$ Its audit for the March 2011 Citizen Report Card on the Constituency Development Fund (CDF) and the Local Authority Transfer Fund (LAFT) for 20 constituencies and 5 local authorities revealed that funds amounting to $24 \%$ for the CDF and $25 \%$ for LAFT for the financial year 2007/2008 in the sampled constituencies and authorities were mismanaged. ${ }^{83}$ Another Citizens group in Kenya, the Muslims for Human Rights (Muhari) a community based association helps to monitor the use by MPs of budgets given to them to distribute as grants to their constituencies. ${ }^{84}$ Similarly in Tanzania,

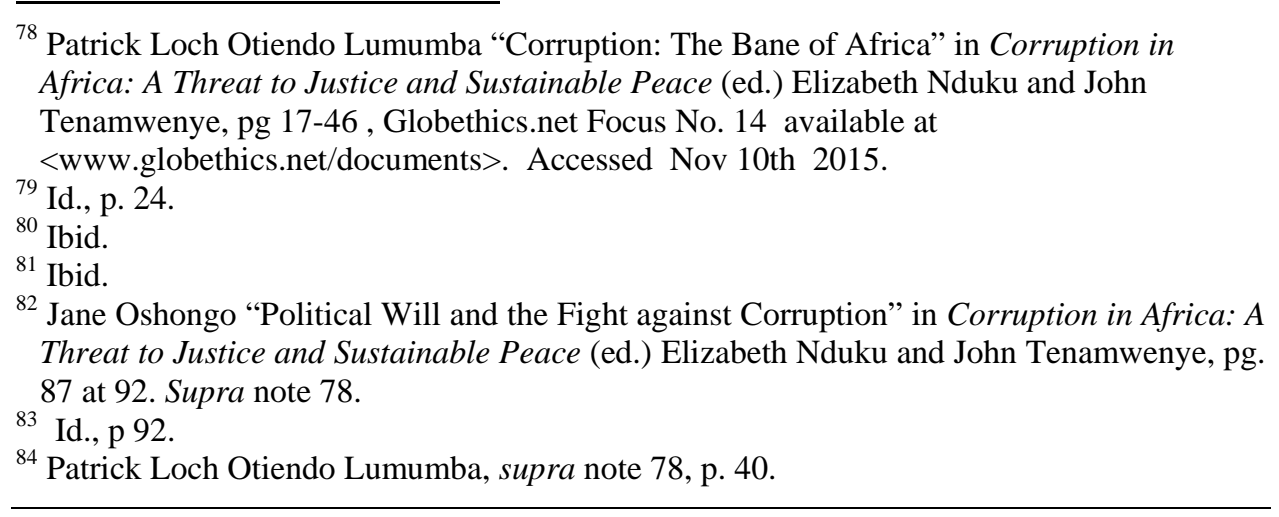


the media and citizens organizations have been efficient in fighting against corruption. ${ }^{85}$

Best practices in legislation and enforcement are also recommended. For example, provision for private citizens' oversight of the anti-corruption fight can be included in anti-corruption statutes of Nigeria as is the case with the Hong Kong Independent Commission Against Corruption (ICAC). The law provides for four citizens advisory committees made up of private citizens. ${ }^{86}$ The citizen committees are: the Advisory Committee on Corruption; (oversees general policy direction of ICAC) the Operations Review Committee; (general oversight of each of ICAC's departments) the Corruption Prevention Advisory Committee; and the Citizen Advisory Committee on Community Relations. ${ }^{87}$

Another critical factor which has helped in the success of anti-corruption commissions in Singapore (Corrupt Practices Investigation Bureau (CPIB) and Hong Kong (ICAC) is the presence of strong political will and strong support of the political authority in the anti-corruption war. ${ }^{88}$ Other recommended best practices for the Nigerian anti- corruption effort from the Singapore experience are the need to have effective anti-corruption laws, for example laws that clearly define the meaning of corruption and includes amongst corrupt acts giving and receiving of 'customary gifts', establishes an effective anti-corruption Agency, (for example the CPIB), ensures effective adjudication (for example an independent judiciary and insulation of the judiciary from politics), and an efficient government (for example a responsive public service willing to cut red tape and ditch archaic methods of public administration.) ${ }^{89}$ These recommended practices have clearly identified and provided solutions for sociological factors like culture, custom, and poor governance practices which fuel corruption. In view of the critical contribution of corruption to the burgeoning crime problems of Nigeria and other African and developing countries, it is recommended that they adopt these best practices in the fight against the malaise if they must achieve any success in the war against crime.

85 Conrad John Masabo 'Corruption and Fraudulent Culture: The Case of Tanzania', in Corruption in Africa: A Threat to Justice and Sustainable Peace (ed.) Elizabeth Nduku and John Tenamwenye, p. 145 at 165, supra note 78.

${ }^{86}$ Patrick Meagher, Anti-Corruption Agencies: A Review of Experience. World Bank 2002. Available at <www.1.wordbank.org/.../anti-corrupt/.../summaryWBpaperA>... Accessed on Nov $7^{\text {th }} 2015$

${ }^{87}$ Id., p 19.

${ }^{88}$ Koh Teck Hin "National Anti-Corruption Strategy: the Singapore Experience. available at $<$ www.unafei.or.jp/english/pdf/RS-No.86/No.86-14VE)> . Accessed on Nov 7 2015

89 Ibid. See also Jon S. T. Quah "Anti-Corruption Agencies in Four Asian Countries: A Comparative Analysis'. International Public Management Review, Vol 8, issue 2, 2007 Electronic Journal available at http.//www.ipmr.net accessed on Nov. 10th 2015. 


\section{Conclusion}

It has been argued in this paper that previous responses by the political authority to the identified crime problems have either been mostly legalistic or based on the law enforcement model, without taking adequate cognisance of the guidance which could be provided by a proper understanding of crime theories. This is a superficial approach to combating crime, as the major causes of crime are ignored thereby. As a result, such crimes continue unabated in society. In spite of the vigorous efforts of the law enforcement agencies, crime problems will be better tackled if government and other relevant stakeholders understand and apply crime theories in the fight against crime. Criminal policy makers should make conscious efforts towards ensuring that crime theories are inculcated and applied by the operators of the criminal justice system, such as law enforcement agents, prosecutors, judicial officers and prison/welfare officers. The exhaustive study of crime theories should be introduced into the inaugural and continuous training programmes of operators in the criminal justice network. Lastly Nigeria should learn from the experience of countries with effective practices in applying theory to practice in tackling corruption, which is the root cause of its crime problems. 